\title{
EMIL LASK: MIĘDZY NEOKANTYZMEM A POSTNEOKANTYZMEM
}

Artykuł przedstawia filozofię Emila Laska jako filozofię wychodzącą od problematyki typowo neokantowskiej, a jednocześnie kładącą podwaliny pod nową perspektywę filozofowania - postneokantyzm. Lask wychodzi od ustaleń filozofii Heinricha Rickerta, wprowadzając wiele rozwiązań i pomysłów, które później wykorzystuje Martin Heidegger. Omówione zostają te elementy filozofii Laska, które świadczą o innowacyjności jego podejścia, a mianowicie: zainteresowanie problemem materialnej strony poznania, projekt logiki przedmiotu, twierdzenie o logos-immanencji przedmiotu, zasada materialnej determinacji formy, ontologiczna teoria prawdy, problem podmiotu konkretnego. Mimo iż Lask sam nie tworzy jeszcze ontologii, jest tym neokantystą, który otwiera perspektywę filozofii transcendentalnej na problematykę ontologiczną. Już w jego rozważaniach staje się jasne, że nie da się tworzyć teorii poznania bez ontologii.

\section{Wstęp}

Celem artykułu jest krótkie przedstawienie filozofii Emila Laska (1875-1915) jako filozofii wychodzącej od problematyki typowo neokantowskiej, a jednocześnie kładącej podwaliny pod nową perspektywę filozofowania - postneokantyzm. W literaturze przedmiotu (zarówno niemieckiej ${ }^{1}$, jak i polskiej ${ }^{2}$ ) niejednokrotnie zwraca-

${ }^{1}$ Zob. K. Hobe Zwischen Rickert und Heidegger. Versuch über eine Perspektive des Denkens von Emil Lask „Philosophisches Jahrbuch” 1971 nr 78 s. 360-376; Th. Kisiel Heideggers Dankesschuld an Emil Lask. Sein Weg vom Neufichteanismus zur Hermeneutik der Faktizität [w:] Heidegger und der Neukantianismus C. Strube (ed.) Würzburg 2009 s. 109-130; tenże The genesis of Heidegger's Being and Time, Berkley-Los Angeles-London 1995. 
no już uwagę, że Lask jest filozofem pośredniczącym między Heinrichem Rickertem i Martinem Heideggerem. Wychodzi on wszakże od wielu ustaleń filozofii Rickerta, sam wprowadzając rozwiązania i pomysły, które później wykorzystuje Heidegger, programowo odcinający się od filozofii neokantowskiej, ale właściwie tylko na poziomie deklaracji.

Jeżeli pojawiają się wątpliwości, czy Richard Hönigswald jest postneokantystą, czy raczej jeszcze neokantystą, czy jego teoria przedmiotu może zostać uznana za ontologię, to podobne wątpliwości pojawiają się w odniesieniu do Heideggera. Projektowana przez tego ostatniego ontologia nie jest wcale ontologią w klasycznym znaczeniu tego terminu, nie jest teorią bytu, lecz teorią rozumienia bytu (czy jak chce Heidegger - rozumienia bycia). Teoria rozumienia bycia ujmuje problem bycia/bytu od strony podmiotowej. Heidegger pozostaje transcendentalistą; pytanie o bycie sprowadza się u niego do pytania o sposób bycia człowieka jako tego, który bycie rozumie, który dokonuje interpretacji bycia, który tworzy koncepcje bycia. Wczesna filozofia Heideggera jest, bez wątpienia, filozofią podmiotu ${ }^{3}$. Heidegger deklaruje, że jest ona zupełnie nową perspektywą i nie ma nic wspólnego z perspektywą neokantowską. Jego deklaracje nie są jednak przekonujące i badacz jego myśli w żadnym razie nie może na nich poprzestać. Można by więc nie tylko w przypadku Hönigswalda, ale także w przypadku Heideggera powiedzieć, że nie są oni jeszcze typowymi postneokantystami - takimi jak Hartmann czy Jaspers. Można też twierdzić, że już nimi są ze względu na przewagę pewnego typu problematyki. Wtedy jednak także Emil Lask jest już częściowo postneokantystą.

\section{Emila Laska interpretacja filozofii Kanta}

Według sformułowania Kanta zadaniem filozofii transcendentalnej jest a priori rozwinięcie systemu pojęć (kategorii) odnoszących się do przedmiotów naszego poznania ${ }^{4}$. Analiza naszych władz poznawczych ma więc być źródłem ontologii rozumianej jako teoria kategorii. Ma to być możliwe dzięki wysuniętej przez Kanta hipotezie, że „to przedmioty muszą się dostosowywać do naszego poznania”. „Jeżeli oglądanie przedmiotów miałoby się stosować do ich własności, to nie rozu-

${ }^{2}$ A. Przyłębski Obecność Laska we wczesnej twórczości Heideggera [w:] tegoż W poszukiwaniu królestwa filozofii. Z dziejów neokantyzmu badeńskiego Poznań 1993 s. 138-146.

${ }^{3}$ Jeśli chodzi o najpóźniejszy okres filozofowania Heideggera, gdzie postuluje on, by człowiek przestał aktywnie odnosić się do bycia, a jedynie biernie w bycie się wsłuchiwał, stając się jak sam to określa - tzw. „pasterzem bycia”, można go interpretować jako próbę odejścia w stronę perspektywy przedmiotowej (a więc ontologicznej). Nadal jednak to człowiek jest tym, który bycia słucha, i - jak twierdzi Heidegger - bez człowieka nie istniałoby coś takiego, jak prawda.

4 ,Transcendentalnym nazywam wszelkie poznanie, które zajmuje się w ogóle nie tyle przedmiotami, lecz naszym sposobem poznawania tych przedmiotów, o ile ten sposób ma być a priori możliwy. System takich pojęć nazywałby się filozofią transcendentalną". I. Kant Krytyka czystego rozumu R. Ingarden (tł.) Kęty 2001 wyd. II s. 68 (B 25).

5 Tamże, s. 36 (B XVI). 
miem, jak można by o nich cokolwiek wiedzieć a priori, jeżeli natomiast przedmiot jako obiekt zmysłów stosuje się do własności naszej zdolności oglądania, to mogę sobie całkowicie dobrze przedstawić tę możliwość" ${ }^{6}$. Inne sformułowanie tej zasady odnajdujemy pod postacią Kantowskiej najwyższej zasady sądów syntetycznych a priori, która brzmi następująco: „warunki możliwości doświadczenia w ogóle są zarazem warunkami możliwości przedmiotów doświadczenia i mają dlatego przedmiotową ważność w syntetycznym sądzie a priori" ${ }^{\text {"7 }}$.

Sposób interpretacji Kantowskiej najwyższej zasady sądów syntetycznych a priori, thumaczącej możliwość apriorycznego sformułowania tabeli kategorii (ontologii), stanowi ważny element różnicujący odmienne kierunki interpretacji oraz rozwoju zapoczątkowanej przez niego drogi myślowej. Zasada ta, jeśli się jej dokładnie przyjrzeć, mówi jedynie tyle, że jeśli dzięki analizie naszych władz poznawczych ujawnimy warunki możliwości doświadczenia, to tym samym odsłonimy także warunki możliwości przedmiotów doświadczenia. Poznane dzięki krytyce rozumu kategorie poznawcze są więc z konieczności także kategoriami przedmiotów. Zasada ta jednak nie głosi - jak chcieliby niektórzy jej interpretatorzy że kategorie przedmiotów wyczerpują się w kategoriach poznawczych zawartych w podmiocie ${ }^{8}$. Nie oznacza ona więc, iżby całe bogactwo kategorii przedmiotowych (cała ontologia) dało się wyprowadzić a priori jedynie na podstawie analizy sposobu poznawania podmiotu. Kant zaznacza: „tylko to z rzeczy poznajemy a priori, co sami w nie wkładamy"'. Reszty nie możemy poznać a priori, ale to nie znaczy, że w ogóle nic nie możemy poznać. Do tego jest już jednak potrzebne poznanie empiryczne. Kantowska nauka o formie i materii poznania oraz stanowiące nieodłączny element jego filozofii pojęcie rzeczy samych w sobie (rzeczy takich, jakimi są same w sobie) stoją w sprzeczności z neokantowską interpretacją transcendentalizmu, w której przedmiot jest nie tyle poznawany, co w całości stwarzany przed podmiot ${ }^{10}$.

Zgodnie z neokantowską interpretacją transcendentalizmu, stanowiącą punkt wyjścia filozofii Emila Laska, rdzeń filozofii Kantowskiej stanowi logika transcendentalna. Rozwijać filozofię transcendentalną Kanta oznacza więc dla neokantystów rozwijać Kantowską logikę transcendentalną. Warto jednak w tym miejscu podkreślić, że logika Kanta oraz to, co neokantyści (nawiązując do filozofii Kanta)

\footnotetext{
${ }^{6}$ Tamże (B XVII).

${ }^{7}$ Tamże, s. 196 (A 158, B 197).

${ }^{8}$ Więcej na ten temat zob. A. Pietras Pojęcie kategorii a problem granic poznania. Nicolai Hartmann a Immanuel Kant „Czasopismo Filozoficzne” 2006 nr 1 s. 22-40.

${ }^{9}$ I. Kant Krytyka... wyd. cyt. s. 37 (B XVIII).

${ }^{10}$ Te dwa elementy filozofii Kanta: pojęcie rzeczy samej w sobie oraz rozróżnienie materii i formy poznania, stanowią jądro, wokół którego ogniskują się postneokantowskie interpretacje jego filozofii. Nicolai Hartmann szczególną wagę przywiązuje do pojęcia rzeczy samej w sobie, a Emil Lask (za nim zaś Martin Heidegger) - do problemu materialnej strony poznania. Oba te zagadnienia ściśle się ze sobą wiążą, a ich podkreślanie prowadzi do realistycznej wykładni filozofii Kanta.
} 
rozumieli pod nazwą logiki, niewiele ma wspólnego ze współczesnym pojmowaniem tego terminu. Rozwijająca się dzisiaj z dużym powodzeniem współczesna zmatematyzowana logika formalna, którą przeciętny użytkownik języka ma na myśli, mówiąc o „logice”, za czasów panowania filozofii neokantowskiej dopiero zaczynała się rodzić. Logika, stanowiąca - zdaniem neokantystów - rdzeń transcendentalizmu, to logika materialna, czy mówiąc inaczej - po prostu ontologia. Zresztą sam Kant określa projektowaną przez siebie fillozofię transcendentalną mianem ontologii. Rozróżnienie na logikę formalną i materialną będzie stanowiło bardzo ważny moment w naszych rozważaniach, głównie ze względu na sposób pojmowania wzajemnej relacji między nimi. Neokantyści byli bowiem przekonani, iż logikę materialną można z powodzeniem wyprowadzić z logiki formalnej, że kategorie odpowiadające poszczególnym dziedzinom przedmiotowym można wyprowadzić a priori, rozwijając naukę o sądzie. Sam Kant wyprowadza przecież swoją tablicę dwunastu kategorii z podstawowych form sądów, co - zdaniem wielu jego krytyków - stanowi najsłabszy element jego filozofii.

Lask wyraźnie sprzeciwia się temu elementowi filozofii transcendentalnej swych nauczycieli, zwracając uwagę na fakt, że pomimo sposobu, w jaki królewiecki myśliciel przeprowadza dedukcję kategorii, w jego myśli odnaleźć można pewne idee, które wyraźnie wskazują na niemożliwość czysto apriorycznego wyprowadzenia kategorii przedmiotowych. Za punkt wyjścia swojej interpretacji myśli Kanta, a jednocześnie własnego projektu filozofii transcendentalnej, Lask obiera Kantowską naukę o formie i materii poznania. To właśnie m a t e r i a l n a strona poznania, na którą Kant jedynie wskazał, nie przeprowadzając jej szczegółowych badań, zostaje sproblematyzowana w myśli Laska, a później także u nawiązującego do niego Heideggera. Wydaje się więc, że można mówić o pewnego rodzaju zwrocie w rozumieniu transcendentalizmu dokonującym się za sprawą Laska - zwrocie, który w późniejszym okresie zaowocował Heideggerowską ideą hermeneutyki faktyczności.

Emila Laska interpretacja filozofii Kanta, a tym samym jego własny projekt filozoficzny, ogniskują się wokół dwóch zagadnień, które - jego zdaniem - przez samego Kanta nie zostały dostatecznie rozważone. Są to: (a) problem formy i materii poznania oraz (b) problem poznania filozoficznego.

\section{(a) Problem formy i materii poznania}

Jak wiadomo, Kant rozróżnia formę i materię poznania: „W każdym poznaniu należy odróżnić materię, to jest przedmiot, oraz formę, to jest sposób, w jaki poznajemy przedmiot" ${ }^{\prime 1}$. Po wprowadzeniu tego rozróżnienia filozof przechodzi jednak do rozważenia formalnej strony poznania, każąc nam jedynie pamiętać o jej drugim materialnym biegunie, który nie pozwala nam wykraczać poznaniem poza przedmioty

\footnotetext{
${ }^{11}$ I. Kant Logika. Podręcznik do wykładów A. Banaszkiewicz (tł.) Gdańsk 2005 s. 47.
} 
możliwego doświadczenia. Kant wcale nie przedstawia - jak sam to nazywa - warunków możliwości doświadczenia, lecz raczej warunki możliwości poznania doświadczalnego (poznania opartego na doświadczeniu). Tłumaczy, jak możliwe jest poznanie przedmiotów doświadczenia, nie tłumacząc jednak, jak to się dzieje, że są nam one „dane” w doświadczeniu. Jak trafnie zauważa Nicolai Hartmann, Kantowska krytyka rozumu była krytyką poznania apriorycznego. Zadaniem, jakie stawia sobie Kant, jest uzasadnienie możliwości poznania a priori (możliwość sądów syntetycznych a priori). Możliwość poznania a posteriori wydaje mu się oczywista, nie zostaje więc sproblematyzowana. Ten brak zostaje zauważony przez Laska, który kładzie tak duży nacisk na materialną stronę poznania, uważając, iż rozważenie tego zagadnienia stanowi konieczne uzupełnienie myśli Kanta.

\section{(b) Problem poznania filozoficznego}

Filozofia transcendentalna Kanta rozważa problem możliwości poznania doświadczalnego. Kant nie pyta jednak o to, jak jest możliwe poznanie filozoficzne. O to idąc dalej - zapytają Lask i Heidegger. Pytanie o możliwość poznania filozoficznego wiąże się z pytaniem o kategorie tego typu poznania, a co za tym idzie - z pytaniem o miejsce logiki ${ }^{12}$. Kant stworzył logikę poznania przedmiotowego, Lask chce ją uzupełnić logiką poznania fillozoficznego: „A więc w Kantowskiej nauce o kategoriach brak miejsca dla kategorialnych form jego własnej spekulacji, a krytyka rozumu teoretycznego wypiera się logicznych warunków swojej własnej krytyki rozumu"13. To zarzut, który wobec Kantowskiej krytyki wysuwano już wcześniej ${ }^{14}$.

Lask pisze: „Bycie (istnienie) tego, co bytujące, należy już do tego, co obowiązujące, a tym samym do tego, co nie-bytujące (nie-bytu), rzeczywistość tego, co rzeczywiste, należy już do tego, co nierzeczywiste" ${ }^{15}$. Ten być może zawile brzmiący fragment, oddający istotę tego, co Heidegger nazwał później r ó ż n i c ą o nt o l o g i c z n ą, mówi o czymś prostym i całkiem oczywistym. Kategorie takie jak bycie, rzeczywistość, czy inne, rozważane przez filozofię transcendentalną, są określeniami sfery bytu, same jednak do niej nie należą. Skoro tak, to możliwość ich badania, ujmowania, mówienia o nich musi zostać osobno wyjaśniona. Kant nie wyjaśnił możliwości ich poznania, a wyjaśnił jedynie, jak za ich pomocą można

${ }^{12}$ Zob. S. G. Crowell Die Heimatlosigkeit der Logik bei Lask und Heidegger [w:] Heidegger... wyd. cyt. s. 93-107.

${ }^{13}$ E. Lask Die Logik der Philosophie und die Kategorienlehre. Eine Studie über den Herrschaftsbereich der logischen Form [w:] tegoż Gesammelte Schriften t. II E. Herrigel (ed.) Tübingen 1923 s. 263.

${ }^{14}$ Być może jest to problem całej filozofii transcendentalnej. Por. L. Wittgenstein Tractatus logico-philosophicus B. Wolniewicz (tł.) Warszawa 2004 (teza 6.64): „Tezy moje wnoszą jasność przez to, że kto mnie rozumie, rozpozna je w końcu jako niedorzeczne; gdy przez nie - po nich wyjdzie ponad nie. (Musi niejako odrzucić drabinę, uprzednio po niej się wspiąwszy)”.

${ }^{15}$ E. Lask Die Logik der Philosophie... wyd. cyt. s. 46. 
poznawać byty, które są przez nie określane. Kant wyjaśnił, jak poznajemy to, co rzeczywiste, to, co bytujące, to, co czasowe, to, co uwarunkowane przyczynowo; jego logika transcendentalna jest logiką poznania naukowego. Nie wyjaśnił jednak, jak doszedł do odkrycia tych warunkujących wszelki ujmowany w doświadczeniu byt form apriorycznych; nie stworzył logiki poznania filozoficznego.

Projektowana przez Laska logika filozofii ma za zadanie zbadać warunki możliwości poznania filozoficznego (poznania transcendentalnego), kategorie filozoficzne, czy mówiąc jeszcze inaczej - tzw. kategorie refleksyjne. S. G. Crowell pisze:

Jeśli istnieje zasadnicza różnica między rzeczą (przedmiotem) logiki transcendentalnej a przedmiotami poszczególnych nauk, które badają to, co bytujące, to zadaniem filozoficznej teorii logiki jest rozjaśnienie źródłowego stosunku (,przed-stosunku”) między tym, co bytujące, a jego nieistniejącym (niebytującym) obowiązywaniem ${ }^{16}$.

Lask i Heidegger rozwijają ten problem w swojej nauce o sensie, która $\mathrm{z}$ jednej strony - związana jest $\mathrm{z}$ (charakterystycznym dla neokantystów, a także dla Husserla) odpsychologizowaniem sensu, z drugiej zaś - ma unikać jego umetafizycznienia. Aby go uniknąć, w miejsce teorii dwóch światów Lask wprowadza swoją teorię dwóch elementów. Problem logiki filozoficznej naprowadza go na nową myśl na temat związku formy i materii poznania. W tym miejscu łączą się nasze dwa wyjściowe problemy (a i b).

\section{Zasada materialnej determinacji formy}

Nawiązując do Kantowskiej nauki o formie i materii poznania, Lask pisze o dualizmie logicznej formy i alogicznej materii. Zarówno obszar bytu, jak i identyczne z nim królestwo teoretycznego sensu zbudowane są ze sfery teoretycznego obowiązywania jako formy oraz ze sfery nieobowiązującego tego, co zmysłowe, jako materii. „Teoria dwóch światów zostaje przekształcona w teorię dwóch elementów”"17. Oznacza to przede wszystkim, iż podział na materię i formę ma w teorii Laska charakter funkcjonalny, a nie substancjalny. Bycie formą i bycie materią to pojęcia relacyjne, mające sens tylko w odniesieniu do siebie. Coś nie jest po prostu formą lub materią, lecz jest formą dla jakiejś materii lub materią dla jakiejś formy. Dlatego formy poznania przedmiotowego mogą stać się materią poznania filozoficznego, które posługuje się swoimi własnymi formami (formami form). Istotne jest tutaj to, że - zgodnie z teorią Laska - forma jest ontologicznie zależna, nie ma swojego własnego niezależnego istnienia. „Zawartość obowiązywania jest jedynie pustą formą, oczekującą wypełnienia przez «materiał» lub «treść»”,18. „Forma jest jasno-

\footnotetext{
${ }^{16}$ S. G. Crowell Die Heimatlösigkeit der Logik... wyd. cyt. s. 96.

${ }^{17}$ E. Lask Die Logik der Philosophie... wyd. cyt. s. 45.

${ }^{18}$ Tamże, s. 33.
} 
ścią, w której materiał już zawsze stoi" ${ }^{19}$. Nie istnieje więc żadne autonomiczne królestwo form (które mogłoby być badane przez metafizykę). Crowell pisze: „Rozróżnienie na formę i materię nie opiera się na «rzeczywistej», lecz jedynie na czysto refleksyjnej różnicy; forma nie jest niczym innym, jak po prostu jasnością, poznawalnością (zrozumiałością) samego materiału"20. Lask krytykował Rickerta właśnie za to, że w filozofii tego ostatniego formy ,wiszą w powietrzu”. Forma jest integralnym elementem przedmiotu (złożonego $\mathrm{z}$ formy i materii); jedynie w myśli możemy wyabstrahować formę od materii.

Lask formułuje zasadę materialnej determinacji for$\mathrm{m}$ y (Prinzip der Materialbestimmtheit der Form), zgodnie z którą wszelka różnica jakościowa między formami tkwi w materii, a nie $\mathrm{w}$ formie, a mianowicie $\mathrm{w}$ tym, do ujęcia jakiej materii dana forma się nadaje. „Określoność pojedynczych form jest warunkowana wprawdzie logicznie, ale nie na wskroś logicznie, nie poprzez to, co logiczne, lecz przez alogiczny materiał, kategorie bytu wywodzą się ze szczegółowości pozbawionego znaczenia materiału, odbicia tam ujawnionej określoności”21. „Pojedyncze formy są w swojej specyficzności całkowicie określone poprzez obcy logosowi materiał"22. Innymi słowy, forma jest taką, jaką jest ze względu na materiał, który organizuje. Dlatego nauka o kategoriach (logika transcendentalna) nie może abstrahować od materii (materiału), który ujmowany jest za pomocą opisywanych przez nią form (kategorii). Tym samym logiki materialnej nie da się wyprowadzić z logiki formalnej, logiki przedmiotu nie można wydedukować z logiki sądu.

W ujęciu Laska wszelki materiał jest już w pewien sposób uformowany. Jak trafnie opisuje to Crowell: u Laska „być materiałem nie oznacza być poza prze-

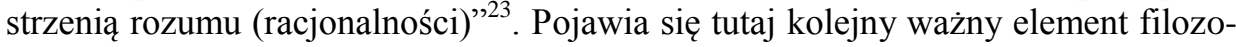
fii Laska, a mianowicie przekonanie o tym, że przedmioty poznania są wprawdzie transcendentne $\mathrm{w}$ stosunku do podmiotu poznającego, lecz mimo to logos-immanentne. Co więcej, wydaje się to być prosta konsekwencja przyjęcia zasady materialnej determinacji formy. Skoro bowiem forma posiada swą określoność dzięki temu, do ujęcia jakiego materiału się nadaje, to tym samym materia musi zawierać już w sobie pewne (przynajmniej potencjalne) określenie kategorialne, musi potencjalnie wskazywać na odpowiadającą jej formę.

Pojawia się tutaj ważna - z punktu widzenia rodzących się nowych ontologii intuicja, zgodnie z którą przedmioty - mimo że transcendentne w stosunku do podmiotu - nie znajdują się wcale poza sferą racjonalności. Podmiot nie jest bowiem jedynym źródłem racjonalności. Przedmioty posiadają własną, odpowiadającą im

${ }^{19}$ S. G. Crowell Die Heimatlösigkeit der Logik... wyd. cyt. s. 97.

${ }^{20}$ Tamże.

${ }^{21}$ E. Lask Die Logik der Philosophie... wyd. cyt. s. 62-63.

${ }^{22}$ Tamże, s. 63.

${ }^{23}$ S. G. Crowell Transcendental Logik and Minimal Empiricism: Lask and McDowell on the unboundedness of the conceptual [w:] Neo-Kantianism in contemporary philosophy R. A. Makkreel, S. Luft (red.) Bloomington, Indianapolis 2010 s. 163. 
racjonalność. Wydaje się, że także sam Kant nigdy nie twierdził, że jedynie podmiot jest źródłem racjonalności. Zdaniem Laska, Kantowski przewrót kopernikański nie polegał wcale - jak często się uważa - na podporządkowaniu przedmiotów podmiotowi, lecz na rozszerzeniu sfery logiki także na przedmiotowość. Stąd już tylko krok do obecnego w filozofii Hartmanna rozróżnienia na kategorie poznania i kategorie bytu oraz - możliwego dopiero na gruncie tego rozróżnienia - pytania o zakres ich pokrywania się.

\section{Sens przewrotu kopernikańskiego}

Zdaniem Laska, u Kanta przeciwieństwo realnego i czysto logicznego znaczenia jest kruche i obraca się w przeciwieństwo wewnątrz tego, co logiczne. Realność zostaje wciągnięta do sfery tego, co logiczne. To, co logiczne (logika), rządzi w przedmiotach jako ich bycie, rzeczowość, przyczynowa konieczność. Jest to możliwe tylko dzięki rozszerzeniu sfery logiki na przedmiotowość i w niej, ale nie poprzez zapanowanie logiki ,nad" p r z e d m i o t o w o ś c i ą ${ }^{24}$. Włączenie przedmiotowości w obszar logiki oznacza, iż logika będzie zajmowała się zarówno kategoriami sądzenia (poznawania), jak i kategoriami przedmiotów. W neokantyzmie rozróżnienie to nie występowało, gdyż przedmiot utożsamiony był z przedmiotem sądu. Lask odróżnia przedmiot występujący i ujmowany przed wydawaniem sądu od przedmiotu sądu. Kategorie pierwszego opisuje logika przedmiotu, a kategorie drugiego - logika sądu.

Ciekawie wypada porównanie rozwiązania Laska z rozwiązaniem Nicolaia Hartmanna, który dokonuje swoistego odwrócenia relacji między logiką a ontologią. Ontologia zajmować się ma wszelkiego rodzaju kategoriami (zarówno bytowymi, jak i poznawczymi), logika natomiast zajmuje się tylko pewnym szczególnym rodzajem kategorii, a tym samym nie obowiązuje dla bytu w ogóle, a tylko dla pewnego szczególnego rodzaju bytu - bytu logicznego. Rozwiązanie Laska jest nieco odmienne od rozwiązania proponowanego potem przez Hartmanna, jednak w istocie swej są one mimo wszystko zbliżone. Lask - podobnie jak Hartmann nie zgadza się bowiem na zapanowanie logiki sądu (kategorii poznawczych) „nad” przedmiotowością. To zakres logiki jako nauki musi zostać poszerzony tak, aby mogła ona uchwycić także kategorie przedmiotowe. W tym sensie logika projektowana przez Laska bliższa jest Hartmannowskiej ontologii niż logice neokantowskiej.

Zdaniem Ingerid Dal, autorki Lasks Kategorienlehre im Verhältnis zu Kants Philosophie $^{25}$, krytycznej pracy pisanej ze stanowiska ortodoksyjnego neokantyzmu, Lask odwraca przewrót kopernikański Kanta. Przywraca on bowiem naukę o prymacie przedmiotu oraz o poznaniu jako odbiciu ${ }^{26}$. Warto przypomnieć, że także

\footnotetext{
${ }^{24}$ E. Lask Die Logik der Philosophie... wyd. cyt. s. 44.

${ }^{25}$ I. Dal Lasks Kategorienlehre im Verhältnis zu Kants Philosophie Hamburg 1926.

${ }^{26}$ Tamże, s. 34.
} 
Ernst Cassirer zarzucał Laskowi teorię odbicia. Zdaniem Dal, Lask powraca do przedkrytycznego realizmu teoriopoznawczego Arystotelesa i tylko terminologia jest u niego Kantowska $^{27}$. Z punktu widzenia ortodoksyjnego neokantyzmu sprawa rzeczywiście może tak wyglądać. Tym bardziej potwierdza to, że Laska interpretacja Kanta bliższa jest rodzącemu się postneokantyzmowi (który można uznać za próbę pogodzenia Kanta z Arystotelesem) niż klasycznemu neokantyzmowi.

Lask powołuje się na przewrót kopernikański Kanta w celu uzasadnienia metagramatycznej koncepcji podmiotu-predykatu. Jego zdaniem, największym osiągnięciem Kanta było zaprzeczenie metalogicznemu charakterowi przedmiotu. Przewrót kopernikański Kanta polegał na ustanowieniu identyczności form przedmiotów i form logicznych (form poznawczych). Mamy więc tutaj nadal do czynienia ze skrajną interpretacją najwyższej zasady sądów syntetycznych a priori jako tezy o całkowitej identyczności kategorii poznawczych i kategorii bytowych, interpretacją, która - jak starałam się to wykazać w innym miejscu ${ }^{28}$ - pojawia się później u Heideggera. Mimo to Laska interpretacja Kanta istotnie różni się od interpretacji neokantowskiej z tego względu, że mamy w niej do czynienia $\mathrm{z}$ ontologizacją problematyki poznania. Formy przedmiotów nie są bowiem tym samym, co formy poznawcze - one jedynie z nimi się zgadzają. Taka interpretacja pozwala Laskowi złagodzić problematyczność teorii odbicia. Zdaniem Dal, jest to przeciwieństwo intencji samego Kanta, który przyjmował założenie o źródłowej korelacji między poznającym podmiotem i przedmiotem ${ }^{29}$.

Znowu możemy krótko porównać stanowisko Laska ze stanowiskiem Hartmanna. Według Hartmanna to, że poznajemy byt, możliwe jest dzięki częściowej zgodności kategorii poznawczych i kategorii bytowych. Zanim jednak stwierdzimy ich częściową zgodność, należy je od siebie odróżnić. Hartmann wskazywał, że w filozofii Kanta nie ma miejsca na kategorie przedmiotowe. „Kategorie, które pierwotnie należałyby do obiektu, dla Kanta nie istnieją" ${ }^{30}$. Odróżnienie to jest jednak ważne, kładzie ono bowiem podstawy pod nową ontologię. Z perspektywy postneokantowskiej filozofii Hartmanna filozofia Laska jawi się więc jako postęp w stosunku do filozofii neokantowskiej. Lask głosi wprawdzie tezę o występowaniu w filozofii Kanta całkowitej identyczności kategorii przedmiotowych i kategorii poznawczych, jednak mimo to uznaje sensowność ich rozróżnienia. To, że coś jest identyczne, nie znaczy, że jest tym samym. Przedmioty mają własne odpowiadające im kategorie, nasze poznanie ma własne kategorie, za pomocą których ujmuje przedmioty, jednak - o tyle, o ile poznajemy świat - kategorie te są ze sobą zgodne.

${ }^{27}$ Tamże, s. 39.

${ }^{28}$ Zob. A. Pietras $W$ strone ontologii. Nicolaia Hartmanna i Martina Heideggera postneokantowskie projekty filozofii Kraków 2012.

${ }^{29}$ I. Dal Lasks Kategorienlehre im Verhältnis... wyd. cyt. s. 40.

${ }^{30}$ N. Hartmann Diesseits von Idealismus und Realismus. Ein Beitrag zur Scheidung des Geschichtlichen und Übergeschichtlichen in der Kantischen Philosophie [w:] tegoż Kleinere Schriften t. II: Abhandlungen zur Philosophie-Geschicht Berlin 1957 s. 285. 


\section{Ontologiczna teoria prawdy}

Laska interpretacja przewrotu kopernikańskiego Kanta wraz z zasadą materialnej determinacji formy prowadzą do kolejnego istotnego elementu jego filozofii do ontologicznej teorii prawdy. Zgodnie $\mathrm{z}$ tą teorią pierwotnym miejscem prawdy nie jest - jak chcieli neokantyści - sąd, lecz przedmiot (czy byt). Sąd jest prawdziwy tylko w sposób wtórny, a więc tylko wtedy, kiedy uchwytuje wcześniej daną prawdę bytu (przedmiotu). Tomasz Kubalica wylicza w teorii Laska trzy nośniki prawdy: 1. sąd - może być prawdziwy lub fałszywy; 2. obiekt pierwotny - może odpowiadać prawdzie lub być jej przeciwieństwem; 3. (pozbawiony przeciwieństw) przedmiot, który jest prawdą samą ${ }^{31}$. Lask pisze:

Ale także tutaj rozdarcie na królestwo przedmiotów i „prawdy o nich” nie może zostać utrzymane, lecz prawda przesuwa się znowu do wnętrza samego przedmiotu, jest z nim identyczna. [...] Także tutaj rzecz sama i prawda o niej są jednym i tym samym ${ }^{32}$.

Niemal identyczną teorię odnajdujemy później u Martina Heideggera. Jego słynne pojęcie prawdy jako aletheia (nie-skrytość) ma swoje źródło w Laska pojęciu prawdy.

Interesująco przedstawia się porównanie ontologicznej teorii prawdy Laska i Heideggera z poglądami Nicolaia Hartmanna, który krytykuje wszelką ontologiczną teorię prawdy. $Z$ punktu widzenia filozofii tego ostatniego, mamy tutaj do czynienia z pewnym nieporozumieniem. Prawda - zdaniem Hartmanna - jest, oczywiście, uwarunkowana (ugruntowana) ontologicznie, ponieważ opiera się na relacji ontologicznej między tworem poznawczym a przedmiotem poznania. Twierdzenie to nie prowadzi jednak wcale do ontologicznej teorii prawdy:

Prawda jest wyłącznie kwestią poznania, i to wszystkich jego stopni i warstw, zarówno myślenia i sądzenia, jak i spostrzegania, przedstawienia i wrażenia. [...] Prawda nie jest ani logiczną, ani żadną inną jakością treści, lecz jej zgodnością z realnym przedmiotem $[\ldots]^{33}$.

A zatem Hartmann - podobnie jak Lask, a potem Heidegger - krytykuje neokantowską teorię prawdy. Hartmann ostrzega jednak także przed popadnięciem w drugą skrajność, którą jest właśnie ontologiczna teoria prawdy:

31 T. Kubalica Prymat rozumu praktycznego w logice. Teoria prawdy neokantowskiej szkoby badeńskiej Katowice 2009 s. 121.

${ }^{32}$ E. Lask Die Logik der Philosophie... wyd. cyt. s. 109.

${ }^{33}$ N. Hartmann Zarys metafizyki poznania E. Drzazgowska, P. Piszczatowski (tł.) Warszawa 2007 s. 464-465. 
prawda ma wprawdzie sens ontologiczny, ponieważ odnosi się do bytującej rzeczy, ale jako taka nie jest kwestią ontologiczną, lecz c z y s t o g n o s e o lo g i c z n ą. Prawdą lub nieprawdą nie może być sama rzecz, lecz tylko jej poznanie ${ }^{34}$.

Byt, rzecz, stan rzeczy nie może być prawdziwy lub nieprawdziwy, a jedynie rzeczywisty lub nierzeczywisty. Hartmann słusznie zauważa, że gnoseologiczne pojęcie prawdy uwarunkowane jest ontologicznie; ontologiczne pojęcie prawdy (prawda pojęta jako przysługująca bytowi, rzeczy) musiałoby być uwarunkowane jakoś inaczej, głębiej, na przykład aksjologicznie. Zdaje się, że tak właśnie dzieje się w Heideggerowskiej teorii prawdy, gdzie prawda ontologiczna uwarunkowana jest etycznie. Jeśli chodzi o filozofię Laska, sprawa jest bardziej skomplikowana. Kubalica charakteryzuje Laska pojęcie prawdy jako ontologiczno-aksjologiczne ${ }^{35}$. Całkiem słusznie zwraca jednak także uwagę na fakt, że Lask był przeciwnikiem tezy o prymacie rozumu praktycznego (etyki) w poznaniu, dlatego wyraźnie oddzielał od siebie pojęcia filozofii ważności od pojęć etyki. Ontologiczne pojęcie prawdy Laska uwarunkowane jest aksjologicznie, ale nie poprzez wartości etyczne, lecz poprzez wartości opisywane przez filozofię ważności. Co istotne jednak, postneokantysta Hartmann twierdzi, że powrót do ontologii nie musi wcale oznaczać powrotu do ontologicznej teorii prawdy. Pod tym względem Lask i Heidegger posunęli się więc - z punktu widzenia jego filozofii - za daleko, popadając w jeden z błędów dawnej ontologii. Hartmann wychodzi poza neokantowskie pojęcie prawdy, twierdząc, że prawdziwe mogą być nie tylko sądy, ale także przedstawienia, spostrzeżenia czy wrażenia. Nie posuwa się jednak tak daleko, aby twierdzić, że sama rzecz może być prawdziwa lub nie.

Konsekwencją ontologicznej teorii prawdy jest uznanie prymatu logiki przedmiotu nad logiką sądu. Lask pisze:

Obszar logiki przedmiotu staje się tym, co źródłowe, tym, co pierwotne, całkowicie nienaruszone przez subiektywność i w najwyższym sensie obiektywne, właściwym celem teoretycznego obszaru, natomiast nie-przedmiotowa logika musi przedstawiać się jako ograniczająca się do roli służebnej, jako podporządkowany subiektywności środek ujmowania przedmiotów, krótko mówiąc: jako coś wtórnego, późniejszego ${ }^{36}$.

Hartmann-postneokantysta uzna później ontologię za naukę pierwotną względem teorii poznania.

\footnotetext{
${ }^{34}$ Tamże, s. 465.

${ }^{35}$ T. Kubalica Prymat rozumu praktycznego w logice... wyd. cyt. s. 155.

${ }^{36}$ E. Lask Die Lehre vom Urteil [w:] tegoż Gesammelte Schriften t. II s. 287.
} 


\section{Problem podmiotu konkretnego}

Wszystko, co powiedzieliśmy do tej pory o Lasku, wiąże się z jeszcze jednym - być może mniej wyraźnym, bo słabo przez niego samego rozpisanym - istotnym elementem jego filozofii. Zazwyczaj twierdzi się, że to Heidegger był tym, który zwrócił uwagę na ważność (z gruntu przecież ontologicznego) problemu podmiotu konkretnego. Jednak problem ten znajduje swoje miejsce już w filozofii Laska. Problem poznającego podmiotu konkretnego pozostaje nierozerwalnie związany $\mathrm{z}$ zagadnieniem znaczenia sfery życia $\mathrm{w}$ poznaniu. Lask i Heidegger (podobnie zresztą później Hartmann) zwracają uwagę, że aby adekwatnie uchwycić problem poznania, nie wystarczy pojęcie podmiotu transcendentalnego. Tym, kto poznaje byt, jest przecież zawsze konkretny, indywidualny, żyjący podmiot.

Theodore Kisiel zauważa, że

dokonane przez Laska rozszerzenie Kantowskiej logiki transcendentalnej poza Arystotelesowskie kategorie rzeczywistości empirycznej nakazuje, aby także kategorie, jeśli mają stać się przedmiotem poznania, miały same odpowiadające im kategorie. Ale ta możliwość pokazuje, że istnieje już jakiś przedpoznawczy (prekognitywny) moment, w którym kategorie lub formy same wpierw się prezentują jako dane doświadczenia, zanim zostaną poznane. [...] niezmysłowa forma jest wpierw nie tyle znana, co jedynie doświadczona lub przeżyta. To konstytuuje bezpośredniość ludzkiego życia obfitującego w znaczenie i wartość (= formę) $)^{37}$.

Okazuje się więc, że zadanie stworzenia logiki filozofii, opisującej kategorie poznania filozoficznego, prowadzi Laska do uznania sfery życia za kluczową dla problemu poznania. Stworzona przez Kanta logika przyrodoznawstwa opisuje kategorie konstytutywne, stosowane do ujmowania danej w doświadczeniu zmysłowym materii. Natomiast - znajdująca się nad nią lub głębiej niż ona - logika filozofii zajmuje się opisem kategorii refleksyjnych, które są formami, za pomocą których ujmujemy tamte formy, a więc formami form. Taki sposób myślenia mógłby jednak prowadzić do regresu w nieskończoność - formy form potrzebowałyby kolejnych form, za pomocą których mogłyby zostać uchwycone itd. Jedynym sposobem, aby temu zapobiec, jest uznanie, że ujmowanie kategorii refleksyjnych (form form) ma zupełnie inny charakter. Nie jest to już poznanie (gdyż wszelkie poznanie złożone jest $\mathrm{z}$ formy i materii), lecz rodzaj prekognitywnego doświadczenia, charakterystycznego dla sfery życia. W filozofii Laska pojawia się więc $\mathrm{z}$ a s a d a k onieczności przeżyciowego odniesienia do sfery obowiązywania jako warunek możliwości poznawczego podejścia do s fery doświadczenia. Abyśmy w ogóle mogli poznawać, musimy już żyć w świecie, przeżywać świat. Zasada ta - jak wiemy została później przejęta i szeroko rozpisana przez Heideggera, według którego mo-

37 Th. Kisiel The genesis... wyd. cyt. s. 27. 
żemy poznać bycie, ponieważ wcześniej je rozumiemy, rozumienie to natomiast rozwijamy z konieczności jako istoty żyjące $\mathrm{w}$ świecie pośród innych bytów. Znaczenie życia, rozumianego jako suma pewnej liczby aktów, działań, uczuć czy emocji człowieka, zostaje podkreślone także w filozofii Hartmanna, który pisze o tzw. aktach transcendentalno-emocjonalnych, przypisując im bardzo ważną rolę w poznaniu. Dzięki nim wiemy między innymi, że poznawany przez nas świat rzeczywiście istnieje, a nie jest tylko wytworem naszej świadomości.

Laska - podobnie jak później Heideggera, Hartmanna czy Jaspersa - interesuje zagadnienie podmiotu indywidualnego jako jedno z tych zagadnień, bez których nie da się tworzyć teorii poznania. Problem ten może w ogóle być filozoficznie rozważany, bo - zdaniem Laska - to, co indywidualne, jest także racjonalne. Lask walczy więc $\mathrm{z}$ występującym często $\mathrm{w}$ fillozofii utożsamianiem dwóch rozróżnień: indywidualność - ogólność i irracjonalność - racjonalność. Pisze, że irracjonalne nie jest to, co indywidualne, lecz to, co zmysłowo-naocznościowe, podobnie jak racjonalna nie jest po prostu ogólność, lecz forma kategorialna. W związku z tym „także to, co indywidualne, jest dotknięte przez racjonalną formę, i także abstrakcyjne gatunkowe istnienia (stany) zachowują irracjonalny materiał kategorialny, nie składają się tylko z czystej racjonalnej formy" ${ }^{\text {"38 }}$.

Innym elementem filozofii Laska, świadczącym o jego zainteresowaniu sferą życia, jest sposób, w jaki posługiwał się on językiem. Heidegger był pod wrażeniem intensywności i żywiołowości języka filozofii Laska, który podnosił do rangi terminów filozoficznych obrazowe wyrażenia. Heidegger - o czym przekonał się każdy czytelnik jego dzieł - przejął od niego ten styl. Ale ważniejsze jest to, że styl ten ma swoje teoretyczne uzasadnienie. Skoro bowiem sąd ma tylko wyrażać to, co wcześniej uchwycone czy przeżyte, to język ma dopasowywać się do tego, co uchwyciliśmy i chcemy wyrazić, a nie na odwrót, nie należy zniekształcać tego, co chcemy wyrazić, do możliwości języka. To język powinien stale dopasowywać się do tego, co zostało uchwycone.

\section{Zakończenie}

Filozofia Laska zawiera wiele elementów ważnych dla rodzącego się postneokantyzmu. Uznawany za postneokantystę Heidegger całymi garściami czerpie z filozofii Laska, rzadko jednak do tego się przyznając. Wiele idei powszechnie mu przypisywanych jest tak naprawdę autorstwa Laska. Wystarczy tutaj wymienić: ontologiczne pojęcie prawdy, zainteresowanie materialną stroną poznania (problem faktyczności), zasadę materialnej determinacji formy, wskazanie na znaczenie podmiotu konkretnego oraz sfery życia dla problemu poznania. Hartmann bezpośrednio wspomina o filozofii Laska, twierdząc jednak, że jego filozofii nie można uznać za przykład prawdziwej teorii kategorii (czyli ontologii). Lask wprawdzie dużo o pro-

\footnotetext{
${ }^{38}$ E. Lask Die Logik der Philosophie... wyd. cyt. s. 78.
} 
blemie kategorii pisze, podkreślając konieczność uprawiania zarówno teorii kategorii sądzenia, jak i teorii kategorii przedmiotowych, jednak sam nie rozwija właściwej nauki o kategoriach, nie omawia żadnych konkretnych kategorii. Należałoby przyznać Hartmannowi rację. Lask sam nie tworzy jeszcze ontologii. Jest jednak tym neokantystą, który otwiera perspektywę filozofii transcendentalnej na problematykę ontologiczną, dzięki czemu - już w jego rozważaniach - jasne staje się to, co później chyba najwyraźniej pokazał Hartmann, że $\mathrm{n}$ i e $\mathrm{d}$ a $\mathrm{s}$ i ę $\mathrm{t}$ w orzyć teorii poznania bez ontologi i.

$\mathrm{Na}$ koniec - w celu systematyzacji - wymieńmy jeszcze raz krótko te elementy filozofii Laska, które sytuują jego myśl między neokantyzmem a postneokantyzmem. Są to:

1. Problem te g o, c o d a n e. Potem Heidegger, nawiązując do tego sproblematyzowanego przez Laska zagadnienia, projektuje swoją h e r m e n e ut y k ę fakt y c z n o ś c i. Hartmann pójdzie jeszcze dalej - od problemu tego, co dane w poznaniu, przejdzie do problemu samoistnego niezależnego od poznania bytu, który jest tym, co w poznaniu dane.

2. Zainteresowanie tym, co dane, oznacza zainteresowanie $\mathrm{m}$ a te ri a $\mathrm{ln}$ ą stro ną poznania, która w filozofii Kanta (a tym bardziej neokantyzmu) nie zostaje sproblematyzowana. Kant stwierdza tylko, że materia poznania jest tym, co dane podmiotowi, tym, co pochodzi z zewnątrz, jest nam dane przez zmysły, ale nie pyta o warunki możliwości tego, że coś jest podmiotowi dane z zewnątrz. Przyjmuje jako oczywiste i niewymagające wyjaśnień założenie, że zmysły dostarczają różnorodności danych niepoddanych jeszcze żadnej formie.

Ważna $\mathrm{w}$ tym miejscu jest Laska praca o Fichtem ${ }^{39}$. Fichte był tym, który jako pierwszy w historii filozofii pokantowskiej poruszył ten problem: (a) pytał o to, skąd pochodzi materia poznania (wiemy, że odrzucał rzecz samą w sobie, twierdził więc, że również materia poznania pochodzi z podmiotu, że jest wytworem nieświadomej twórczości podmiotu); (b) zwrócił uwagę na to, że materia poznania jeśli przeciwstawić ją formie poznania - jest irracjonalna. Do problemu poznania włączone zostaje zagadnienie tego, co irracjonalne, rozważane potem szczegółowo przez postneokantystów: Heideggera, Hartmanna i Jaspersa.

3. Lask zainteresowany - obok formalnej - również materialną stroną poznania postuluje stworzenie - obok istniejącej już i rozwijanej w neokantyzmie logiki sądu - tzw. $\log$ i k i p r z e d m i o t u. Wiąże się to z intuicją, według której to, co dane (przedmiot poznania, materialna strona poznania), nie może być całkowicie irracjonalne, skoro może być przez podmiot uchwycone. Lask twierdzi więc, że przedmioty są zarazem tran scende n t n e (w stosunku do podmiotu) i $l$ o g o $s$ - i m m a n e n t n e, co oznacza, że zawierają już same w sobie jakąś racjonalność. Logika przedmiotu ma się zajmować właśnie zagadnieniem właściwej im racjonalności. Można by zadać w tym miejscu pytanie, czy L a s k a

${ }^{39}$ E. Lask Fichtes Idealismus und die Geschichte [w:] tegoż Gesammelte Schriften t. I E. Herrigel (ed.) Tübingen 1923 s. 1-274. 
logikę przedmiotu można traktować już jako rodzaj o n t o l o g i i? Odpowiedź będzie uzależniona od tego, jak zdefiniujemy ontologię.

4. Z a s a a materialnej determinacji formy wskazuje na to, że w filozofii Laska następuje wyraźna zmiana akcentów (w stosunku do filozofii neokantowskiej). Lask nie tylko twierdzi, że trzeba - obok badania formalnej strony poznania - zająć się też jego stroną materialną (jest to jeszcze neutralne twierdzenie, niczego nieprzesądzające). Twierdzi również (i to już nie jest neutralne, tutaj ujawnia swoje stanowisko), że sama forma jest już zdeterminowana przez materię. Nie da się więc tworzyć logiki sądu bez logiki przedmiotu. Nie można rozwijać ich osobno, są one nierozerwalnie ze sobą powiązane. Później Hartmann w podobnym duchu pokaże, że teoria poznania i ontologia są od siebie wzajemnie zależne. Oczywiście u Hartmanna ostatecznie to ontologia jest podstawowa, a teoria poznania może być potraktowana jako jej część. Lask natomiast uznaje logikę przedmiotu za zagadnienie bardziej źródłowe od logiki sądu.

Zasadę materialnej determinacji formy przejmuje od Laska Heidegger. Kisiel twierdzi ${ }^{40}$ wręcz, że jest ona podstawową ideą Heideggerowskiej rozprawy habilitacyjnej $^{41}$.

5. Z powyższej zasady wynika o n t o lo g i c z n a t e o r i a p r a w d y, wiązana zazwyczaj z nazwiskiem Heideggera, ale pojawiająca się już u Laska. Polega ona - krótko mówiąc - na twierdzeniu, że pierwotnym miejscem prawdy nie jest wcale sąd. Heidegger posługuje się greckim pojęciem aletheia na oznaczenie prawdy rozumianej jako odkrytość. Prawda oznacza odkrywanie się, odsłanianie czegoś. Sąd jest prawdziwy o tyle, o ile uchwytuje tę wcześniej daną nam odkrytość. Także tutaj widać, że akcent przeniesiony zostaje na materialną stronę poznania. Sąd jest wtórny w stosunku do odsłaniającej się prawdy, on ją tylko wypowiada. Prawda uchwycona zostaje przed wydaniem sądu. Mamy tutaj do czynienia (z uskrajnionym później przez Heideggera) przeniesieniem akcentu ze s p o nt a n i c z n e j (samorzutnej) na r e c e p t y w n ą stronę poznania. Późny Heidegger uzna nawet, że prawdziwe poznanie jest czysto receptywne.

6. Ostatnim ważnym tutaj elementem filozofii Laska jest jego zainteresowanie p r oble m e m p o d m i o t u k o n k r e t n e g o. W literaturze wskazuje się, że Heidegger wykracza poza neokantyzm i Laska, gdyż mimo iż wciąż zajmuje się podmiotową stroną poznania (analizuje przedmiot jako dany podmiotowi), to jednak przechodzi od 1 o g i k i ku o n t o l o g i i. Lask nie mówi jeszcze o ontologii, lecz jedynie o logice przedmiotu. Przejście od logiki do ontologii nie oznacza u Heideggera przejścia od problemu podmiotu do problemu bytu, lecz przejście od pojęcia podmiotu transcedentalnego do pojęcia konkretnego historycznego podmiotu. Heidegger nie zadowala się rozważaniami nad świadomością konstytuującą (nad podmiotem logicznym) i żąda zakorzenienia abstrakcyjnej teorii podmiotu w filozo-

${ }^{40}$ Th. Kisiel Heideggers Dankesschuld an Emil Lask... wyd. cyt. s. 118.

${ }^{41}$ M. Heidegger Die Kategorien- und Bedeutungslehre des Duns Scotus [1915] [w:] tegoż Gesamtausgabe t. 1: Frühe Schriften Frankfurt am Main 1972 s. 189-411. 
fii żywego dziejowego podmiotu konkretnego. Przyłębski zwraca uwagę, że gdyby nie przedwczesna śmierć Laska, to najprawdopodobniej jego filozofia rozwinęłaby się w podobnym kierunku, gdyż - podobnie jak Heidegger - interesował się on filozofią życia ${ }^{42}$. Trzeci tom dzieł zebranych Laska zawiera teksty związane z tą problematyką. Laska zasada konieczności przeżyciowego odniesienia do sfery obowiązywania jako warunek możliwości poznawczego podejścia do sfery doświadczenia oraz sposób, w jaki filozof ten posługiwał się językiem, zdają się to potwierdzać.

\section{EMIL LASK: BETWEEN NEO-KANTIANISM AND POST-NEO-KANTIANISM}

In this paper the author shows that Emil Lask's philosophy starts with considering of typical Neo-Kantian's questions but at the same time it grounds a new philosophical perspective - Post-Neo-Kantianism. The origin of Lask's research is Heinrich Rickert's theory of judgment, however Lask finds many new solutions and initiates new ideas adopted from him by Martin Heidegger. The article discuss an innovative elements of Lask's thought like: problem of the material side of cognition, logic of object, logos-immanency of object, doctrine of the material determination of form, ontological theory of truth, problem of the individual subject. Although Lask does not create ontology he is the one Neo-Kantian philosopher, who make transcendental philosophy to ask ontological questions. When we study his considerations it starts to be obvious that theory of cognition is not possible without ontology.

Alicja Pietras - e-mail: alicja.pietras@gmail.com

${ }^{42}$ Zob. A. Przyłębski Obecność Laska... wyd. cyt. 